NBSIR 86-3399

Comparison of Measured and Predicted Sensible Heating and Cooling Loads for Six Test Buildings

D.M. Burch

G.N. Walton

B.A. Licitra

K. Cavanaugh

U.S. DEPARTMENT OF COMMERCE

National Bureau of Standards

Gaithersburg, MD 20899

June 1986

QC

n-a-nred for:

100

:ric Power Research Institute

.456

$86-3399$

1986 

D.M. Burch

G.N. Walton

B.A. Licitra

K. Cavanaugh

U.S. DEPARTMENT OF COMMERCE

National Bureau of Standards

Gaithersburg, MD 20899

June 1986

Prepared for:

Electric Power Research Institute

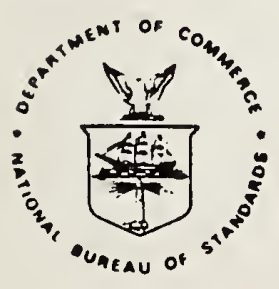

U.S. DEPARTMENT OF COMMERCE, Malcolm Baldrige, Secretary NATIONAL BUREAU OF STANDARDS, Ernest Ambler, Director 
- 
CONTENTS

Abstract................................................

1. Introduction........................................

2. Description of Computer Programs............................2

2.1 Thermal Analysis Research Program (TARP)...................

2.2 Electric Power Research Institute Methodology for

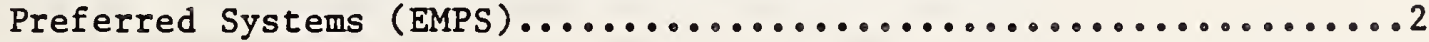

3. Description of the Test Buildings............................2

4. Instrumentation and Measurement Technique....................3

5. Comparisons of Space Conditioning Loads without a Partition Wall......4

6. Comparisons of Space Conditioning Loads with a Partition Wall........7

6.1 Description of Interior Mass Features......................7

6.2 Results...........................................

7. Comparisons of Predicted Space Heating Loads to. Steady-State Theory....8 8. Summary and Conclusions................................ Acknowledgments..........................................

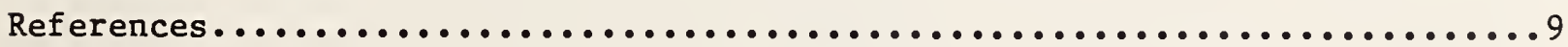
Tables, $1-4 \ldots \ldots \ldots \ldots \ldots \ldots \ldots \ldots \ldots \ldots \ldots \ldots \ldots \ldots \ldots \ldots \ldots \ldots \ldots \ldots \ldots \ldots \ldots \ldots \ldots \ldots$

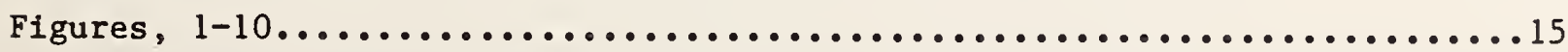




\title{
COMPARISON OF MEASURED AND PREDICTED SENSIBLE HEATING AND COOLING LOADS FOR SIX TEST BUILDINGS
}

\author{
D. M. Burch, G. N. Walton, B. A. Licitra, and K. Cavanaugh
}

\section{ABSTRACT}

Hourly sensible heating and cooling loads for six test buildings were predicted using two computer programs, called TARP and EMPS. The predicted loads were compared to corresponding measured loads for winter heating, spring heating, and summer cooling periods. Both computer programs predicted the general trends of the measured data. During the winter period, cumulative sensible heating loads predicted by TARP agreed with measured loads within an RMS average difference of $11.5 \%$, and predicted peak sensible heating loads agreed within an RMS average difference of $12.1 \%$. During the winter period, poorer agreement was obtained with EMPS. During the summer period, cumulative sensible cooling loads predicted by EMPS agreed with measured loads within an RMS average difference of $14.8 \%$, and predicted peak sensible cooling loads agreed within an RMS average difference of 16.5\%. During the summer period, poorer agreement was obtained with TARP. The agreement between predicted and measured loads is comparable, and in many instances better, than that obtained in similar computer program validation studies.

Keywords: Thermal Analysis Research Program (TARP); EPRI Methodology for Preferred Residential Systems (EMPS); Validation of computer programs; Whole Building Performance; Heating Loads; Cooling Loads; and Energy Conservation.

\section{INTRODUCTION}

Computer programs are currently available that perform hourly building energy simulation analysis. Building designers, architects, and building owners use these computer programs to size HVAC equipment, to predict peak demands, or to predict annual energy costs. Moreover, such programs are used to minimize annual energy costs by investigating trade offs in the envelope design, selection of HVAC systems and equipment, and by analyzing various methods of building operation. In addition, many utility companies are interested in the prediction of accurate hourly space conditioning electrical loads in order to establish the effects of building/system trade offs on utility system loads.

The heat-transfer processes that occur in buildings are very complex and can not be mathematically formulated in a precise manner without incurring excessive amounts of computer time and memory. As a result, the heat-transfer algorithms contained in computer programs contain simplifying approximations. Some of these approximations are discussed later in the paper. In isolated cases, these algorithms may be incorrectly applied. Moreover, computer programs require that the heat-transfer properties for the materials comprising the building envelope be specified as input. In most cases, these heat-transfer properties are obtained from handbooks and may differ from actual values by $10 \%$ or more. These factors cause predicted space conditioning loads to deviate from actual measured loads. In order to determine whether computer programs are sufficiently accurate to permit them to be utilized for the purposes outlined above, a need exists to quantify the difference between computer-predicted and measured space heating and cooling loads for full-size buildings. 
In response to the above interest, the Electric Power Research Institute (EPRI), the research organization representing the electric utility companies, sponsored a study at the National Bureau of Standards (NBS) to verify the accuracy of the computer program, called the EPRI Methodology for Preferred Residential Systems (EMPS) prior to its wide dissemination and use by the electric utility companies. For this study, measured hourly sensible conditioning loads for six test buildings [1,2] are compared to corresponding predicted values using EMPS and the Thermal Analysis Research Program (TARP). TARP is considered to be one of the most sophisticated contemporary computer programs for predicting space heating and cooling loads of buildings because it models many of the heat-transfer processes more precisely than other computer programs. It was believed to provide a good reference computer program for verifying the accuracy of EMPS. EMPS (version 2.1) was previously compared to measured space conditioning loads for the same six test buildings [3]. In the present study, a revised version of EMPS 2.1 containing improved solar algorithms is used.

\section{DESCRIPTION OF COMPUTER PROGRAMS}

\subsection{Thermal Analysis Research Program (TARP)}

TARP is a research computer program developed at NBS. It is written in FORTRAN 77 with an emphasis on program portability. Its computer algorithms are partly based on subroutines from the Building Loads Analysis and Systems Thermodynamics (BLAST) computer program. TARP computes space conditioning loads by performing a detailed heat balance on each zone of a building. TARP is unique in that it determines air exchange between zones and across the building envelope. Transient conduction heat transfer is computed using conduction transfer functions. TARP, however, does not contain HVAC system and equipment simulation algorithms. Further information on TARP is contained in ref. [4].

\subsection{Electric Power Research Institute Methodology for Preferred Systems (EMPS)}

EMPS 2.1 is an integrated package of three computer programs written in FORTRAN that allows users to predict hourly space heating and cooling loads in conventional and passive-solar residences, and to determine the costs to both the owner and the utility of the energy use. In this study, only the energy analysis portion of EMPS is used. The energy analysis portion uses an electrical analog $R-C$ network to calculate transient thermal loads for a building. Up to ten thermally coupled building spaces may be represented. The coupling between spaces includes conduction between partition walls/floors but does not include convective coupling as contalned in TARP. The thermal loads and equipment simulations are carried out simultaneously at each time step ( 1 hour or less). System simulations are provided for central and/or unitary heating and/or cooling systems. A major focus of the EMPS program is on the residential system options, which include two-stage heat pumps, groundcoupled heat pumps, and utility controlled load cycling. The program was developed by Arthur D. Little, Inc. and is currently available from the EPRI Software Center. Further information on EMPS is contained in ref. [5].

\section{DESCRIPTION OF THE TEST BUILDINGS}

Six $20 \mathrm{ft}(6.1 \mathrm{~m})$ by $20 \mathrm{ft}(6.1 \mathrm{~m})$, one room, test buildings with $87-1 / 2 \mathrm{ft}$ $(2.3 \mathrm{~m})$ high ceiling were constructed outdoors at NBS located in Galthershurg. MD. A photograph of one of the test buildings is given in fig. 1. These bulidings have the same floor plan and orientation. 
They were identical, except for the wall constructions, which were as follows:

Building No. 1. Insulated lightweight wood frame,

Building No. 2. Uninsulated lightweight wood frame,

Building No. 3. Insulated masonry (outside mass),

Building No. 4. Uninsulated masonry,

Building No. 5. Log, and

Building No. 6. Insulated masonry (insulation sandwiched between inside and outside mass).

A detailed description of the walls of the buildings is given in ref. [6]. The properties of the walls are given in table 1. The steady-state thermal resistances for the walls of building Nos. 1, 3, 5, and 6, as well as those for building Nos. 2 and 4, were designed to be approximately equivalent, but in fact turned out to be somewhat different. With the exception of building No. 6 , an effort was made to use construction representative of current practices of the United States.

Each building contained two double-hung windows on both the north and south walls. Each window contained an insulating glass glazing fitted with an exterior storm glazing. Each building had a $19.5 \mathrm{ft}^{2}\left(1.81 \mathrm{~m}^{2}\right)$ hollow metal door filled with perlite insulation on the east wall.

The edges of the concrete slab-on-grade floors were insulated with 1-inch-thick (25 mm) polystyrene insulation at both the inner and outer surfaces of the footing. Two-inch-thick (50 mm) polystyrene insulation was installed over the top surfaces of the slab-on-grade floors in order to reduce the effect of seasonal variations in earth heat transfer.

Each building contained a pitched roof forming an attic space vented with soffit and gable vents. Eleven inches ( $280 \mathrm{~mm}$ ) of glass-fiber blanket insulation $\left[R-34 \mathrm{~h} \cdot \mathrm{ft}^{2} \cdot \mathrm{F} / \mathrm{Btu}\left(\mathrm{R}-6.0 \mathrm{~m}^{2} \cdot \mathrm{K} / \mathrm{W}\right)\right]$ was installed over the ceiling.

Each building was equipped with a centrally located $4.1 \mathrm{~kW}$ electric forced-air heating plant equipped with a $13,000 \mathrm{Btu} / \mathrm{h}(3,800 \mathrm{~W})$, split, vapor-compression, conventional residential air-conditioning system.

A detailed description of the heat-transfer properties for the buildings is given in ref. [6].

\section{INSTRUMENTATION AND MEASUREMENT TECHNIQUE}

The instrumentation and measurement technique used have been described in detail in ref.[6]. A brief synopsis is given below.

A weather station was located at the test site. It contained a rotatingcup anemometer for measuring the wind speed, two pyranometers for measuring the hemispherical solar radiation incident on a south-facing vertical surface and a horizontal surface, and a lithium-chloride transducer for measuring the outdoor relative humidity. The outdoor temperature was measured with a thermocouple mounted $1 \mathrm{ft}(0.3 \mathrm{~m})$ from the center of the north wall of an instrument building located at the test site.

The total electrical energy utilized by each building was measured using a wathour meter equipped with a demand metering device that generated a contact 
closure for each 3.6 Wh consumed.

The cumulative sensible cooling load $\left(Q_{S}\right)$ was determined from the relation:

$$
Q_{s}=m^{*} C_{p} \int_{0}^{P} \Delta T \cdot d t
$$

where

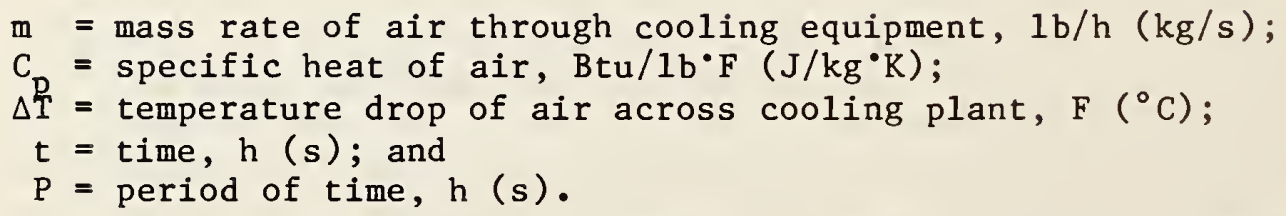

The sensible cooling load was experimentally determined by integrating the temperature drop $(\Delta \mathrm{T})$ during the periods when the air-distribution blower operated. The temperature drop $(\Delta T)$ was measured with a multi-junction thermopile installed between the supply and return of the air conditioning system. The mass flow rate (m) of air through the cooling equipment was measured using a pitot-static alrflow measuring device mounted in a long, straight return duct.

The latent loads were determined by collecting and weighing condensate from the air conditioners at hourly intervals in large cyclinders. These measurements were not meaningful at hourly intervals due to condensation on the interior walls of the cylinders during cool night periods, suction of condensate back into the condensate lines when the air conditioners operated, and time delays between condensation formation and collection in the cylinders. These experimental difficulties prevented meaningful comparisons between predicted and measured hourly latent loads.

The indoor temperature and indoor relative humidity within each bullding were measured at various locations with thermocouples and a transducer, respectively.

Winter infiltration rates for each building were measured under a wide range of outdoor temperatures and wind speeds. The data obtained for each bullding were fitted to an empirical equation. The coefficients for each equation were specified as input to the programs. Summer air infiltration rates for each building were measured and found to be weakly dependent on outdoor conditions. Constant summer infiltration rates were specified as input to the programs. The infiltration rates for the test buildings were less than 0.2 volume changes per hour and had a very small effect on the space heating and cooling loads of the test buildings.

Data acquisition systems having 100 channels were installed in building Nos. 1, 3, and 5. Each system served the building in which it was located, and the even number building located across from it. Data were recorded at hourly intervals.

\section{COMPARISONS OF SPACE CONDITIONING LOADS WITHOUT A PARTITION WALL}

A geometric description of each building including the heat-transfer propertles of its components, an operation schedule that included a constant internal load of about $290 \mathrm{~W}$ and a thermostat set temperature, and an outdoor climatic flle for winter heating, spring heating, and summer cooling periods were speclfled as input to the two computer programs. The thermostat set temperatures were 
$68 \mathrm{~F}\left(20^{\circ} \mathrm{C}\right)$ for heating and $76 \mathrm{~F}\left(24^{\circ} \mathrm{C}\right)$ for cooling. The three periods covered in the analysis were:

winter heating period spring heating period summer cooling period
February 21 - March 5, 1982

April 13 - April 25, 1982

July 25 - August 5, 1982 .

Predicted and measured space conditioning loads were compared during the last three days of each period. Outdoor temperature and solar insolation data for the three periods are given in fig. 2 .

Cumulative sensible conditioning loads for the six test buildings predicted by TARP and EMPS are compared to corresponding measured values in fig. 3. Each comparison consists of three bars. The first bar is the TARP cumulative load, the second bar is the measured cumulative load, and the third bar is the EMPS cumulative load. The height of a bar corresponds to the magnitude of the cumulative load. The cumulative loads predicted by both programs track the general trend of the measured data. From figure $3 B$ and $3 C$, it is seen that a thermal mass effect is present in the spring heating and summer cooling periods. Here the heavyweight masonry and log buildings are seen to consume less space heating and cooling energy than identical lightweight buildings having equivalent thermal resistance in their building envelopes. Wall mass is seen to be more effective when it is placed inside, as opposed to outside, the wall insulation. When this thermal mass effect was experimentally observed, both computer programs predicted the correct relative cumulative load. That is, the ranking of the test buildings and the relative magnitudes of the predicted thermal mass effects were the same as those for the actual test buildings.

The largest percentage differences between predicted and measured cumulative heating loads during the winter period occurred for building No. 6 . A thermographic survey of building No. 6 indicated that this building contained thermal anomalies consisting of missing perlite insulation in the walls. A finite-difference analysis [7] indicated that multi-dimensional heat flow patterns in the walls contributed to the anamolous behavior of building No. 6 .

Hourly sensible conditioning load profiles for the six test buildings predicted by the two computer programs are compared to corresponding measured values in fig. 4 for the winter heating period, in fig. 5 for the spring heating period, and in fig. 6 for the summer cooling period. The hourly sensible conditioning loads predicted by the two computer programs track the general trend of the measured loads. Note that in many instances the TARP and EMPS computer predicted loads tracked each other more closely than the measured loads. This is because both computer programs contain very similar heat-transfer assumptions and approximations, and identical building description data is specified as input to both programs. Predicted and measured cumulative loads, and predicted and measured peak loads, are compared in Table 2 for the winter heating period, in table 3 for the spring heating period, and in Table 4 for the summer cooling period. In each table, the A portion pertains to TARP and the $B$ portion pertains to EMPS. At the bottom of each column, the percentage difference is the root-mean-square (RMS) average percentage difference. relation:

In tables 2-4, the peak space conditioning load $\left(Q_{p}\right)$ was determined using the

$$
Q_{p}=\left(Q_{i-1}+Q_{i}+Q_{i+1}\right) / 3
$$


where $Q_{i-1}=$ space cooling load one hour prior to the peak, $W$;

$\mathrm{Q}_{i}=$ space cooling load at peak, $\mathrm{W}$; and

$Q_{i+1}=$ space cooling load one hour after the peak, $W$.

The above relation was used to smooth out fluctuations in load caused by the on/off operation of the thermostat. Fluctuations in load were particularly apparent in the measured summer cooling loads.

During the winter heating period, better overall agreement was obtained with TARP (see Table 2). For this period, TARP predicted cumulative heating loads within a range from -13.4 to $19.9 \%$ with an RMS average difference of $11.5 \%$ and the peak heating loads within a range from -21.5 to $1.5 \%$ with an RMS average difference of $12.1 \%$. During the same period, EMPS predicted cumulative heating loads within a range from -21.7 to $29.5 \%$ with an RMS average difference of $19.1 \%$ and peak heating loads within a range from -27.6 to $6.1 \%$ with an RMS average difference of $17 \%$.

During the spring heating period (see Table 3), the RMS average differences for both TARP and EMPS tended to be larger than the winter values given in Table 2. A factor that may have contributed to this result is that earth heat transfer is a larger percentage of the overall envelope heat transfer during mild climatic periods. Since the earth heat transfer is imprecisely modeled in both computer programs, larger discrepancies may occur during mild climatic periods. For the spring period, better agreement between measured and predicted loads was obta1ned with TARP.

During the summer period (see Table 4), cumulative cooling loads predicted by TARP agreed with measured values within a range from 7.8 to $36.6 \%$ with an RMS average difference of $24.9 \%$, and peak cooling loads predicted by TARP agreed with measured values within a range from 6.2 to $38.5 \%$ with an RMS average difference of $26.6 \%$. During the same period, EMPS predicted cumulative cooling loads within a range from -1.3 to $30.3 \%$ with an RMS average difference of $14.8 \%$ and peak cooling loads within a range from -9.5 to $29.1 \%$ with an RMS average difference of $16.5 \%$. During the summer period, better overall agreement was obtained with EMPS.

Differences between predicted and measured space heating and cooling loads for the above comparisons were believed to be due to the following factors: uncertainties in the heat-transfer properties specified as inputs to the program; simpl1fying approximations used in the algorithms of the two programs; and experimental error in the measured loads and the weather parameters.

A complete description of the bullding envelopes including the heat-transfer properties for the materials comprising the building envelopes was specified as 1 nput to the programs. Heat-transfer properties were obtained from handbooks and may have differed from actual values by $10 \%$ or more. Variability in the construction and the presence of a few small thermal anomalies may have introduced additional uncertainty. The amount of framing was estimated from photographs taken during the construction of the buildings. Differences may have existed between these estimates and the actual construction.

A series of outdoor temperatures was specified as input to the computer programs and served as a boundary condition. A study of the microclimate surrounding the buildings indicated that the outdoor temperature at different locations varied within a range of $\pm 2 \mathrm{~F}\left( \pm 1^{\circ} \mathrm{C}\right)$ at any instant. The outdoor temperature was considered to be uncertain by this amount.

During the winter heating period, the indoor temperature was specified as a 
constant that corresponded to the average of the hourly indoor temperature measured at the mid-height level. The effect of time fluctuations of the indoor temperature as a result of thermostat control was not taken into account in the computer programs.

Both computer programs contain simplifying approximations. A few of the more important ones include: a uniform indoor temperature; one-dimensional heat transfer; and constant heat-transfer properties. The indoor temperature specified in the computer programs is the mid-height value. The indoor temperature within the buildings was observed to be stratified by as much as $8 \mathrm{~F}\left(4^{\circ} \mathrm{C}\right)$ during certain periods. This caused the floor and ceiling heat-transfer surfaces to be modeled with an inexact boundary condition temperature. Although state-of-the-art, the one-dimensional heat-transfer assumption caused heat transfer at corners and within the earth beneath the slab-on-grade floors to be imprecisely predicted. With regard to the constant property assumption, mean temperature has been shown to have a significant effect on the thermal conductances of insulation materials. Other simplifying assumptions that may have affected the predicted results include isotropic diffuse solar radiation and constant ground reflectance.

With regard to experimental error, the heating loads involved the measurement of electrical energy that was believed to be very accurate having an uncertainty of $\pm 0.25 \%$. On the other hand, the sensible cooling loads were computed as the product of a mass flow rate of air through an air conditioner and an integrated temperature rise across the unit. The airflow measurement was believed to be uncertain by $\pm 5-8 \%$. Including the uncertainty in the temperature difference measurement, the overall uncertainty in the cooling load measurement could have been as large as $\pm 12 \%$.

In the comparisons of figures 4-6, the differences between predicted and measured loads are larger during some periods. For instance, a larger difference occurs during the first day of the heating load comparison for building No. 6 (see figure $4 \mathrm{~F}$ ). It was not possible to identify the specific factor(s) that contributed to these larger differences because of the very large number of parameters specified as input to the programs.

In view of the above uncertainties and simplifying assumptions, the level of agreement between predicted and measured space heating and cooling loads is considered to be good. This level of agreement is comparable and in most cases better than that for other similar computer validation studies cited in the literature $[8-11]$.

\section{COMPARISONS OF SPACE CONDITIONING LOADS WITH A PARTITION WALL}

\subsection{Description of Interior Mass Features}

An east/west partition wall containing a standard-size door opening was installed in building Nos. 2 and 4 (see fig. 7). Each partition wall divided the interior of the building into north and south rooms having approximately equal floor area. The partition walls consisted of nominal $2 \times 4$ in (50 X $100 \mathrm{~mm}$ ) studs with $1 / 2$ in $(13 \mathrm{~mm}$ ) gypsum board installed on either side. The total wall cross section framed was $27 \mathrm{ft}^{2}\left(2.5 \mathrm{~m}^{2}\right)$ out of a total partition wall cross section of $145 \mathrm{ft}^{2}\left(13.5 \mathrm{~m}^{2}\right)$, giving a framing fraction of $19 \%$. Each of the rooms was served by separate supply and return ducts that provided approximately equal volumes of conditioned air to each room. The thermostat for controlling the heating and cooling plant was located $5 \mathrm{ft}(1.5 \mathrm{~m})$ above the floor at the north side of the 
partition wall (see fig. 7). Interior room surfaces were painted with off-white latex paint. For some of the summer tests, $1280 \mathrm{lb}(581 \mathrm{~kg})$ of office type furniture (desks and chairs) was placed in building No. 2 .

\subsection{Results}

A summer cooling test was conducted using building Nos. 2 and 4 with a partition wall but without office furniture from July 18 - Aug. 26, 1983. Hourly sensible cooling loads predicted by TARP and EMPS are compared to corresponding measured values during the last three days of the test period in fig. 8. Good agreement was obtained between computer-predicted and measured results for both programs.

After the furniture was installed in building No. 2, a summer cooling test was conducted from Aug. 31 - Sep. 6, 1983. Hourly sensible cooling loads predicted by TARP and EMPS are compared to measured values for corresponding climatic conditions during the last three days of the test period in fig. 9. As in the case of the previous results, very good agreement was obtained between computerpredicted and measured results.

It should be pointed out that the foregoing results have the limitation that direct solar window gain did not occur because the roof overhang completely shaded the south-facing windows. Therefore, direct solar gain algorithms in the two computer programs were not exercised.

\section{COMPARISONS OF PREDICTED SPACE HEATING LOADS TO STEADY-STATE THEORY}

Weekly average sensible heating loads predicted by TARP and EMPS are plotted as a function of average outdoor. temperature in fig. 10 . For each set of predicted values, a best-fit straight line was obtained for the linear regime of the results. The slope for each of these straight lines is labeled on the plot. The slope corresponds to the overall envelope heat-transfer coefficient $(K)$ defined by the relation:

$$
K=\sum\left(U_{i} \cdot A_{i}\right)+\rho \cdot V \cdot C_{p} \cdot I
$$

where $U_{i}=$ thermal transmittance of the $i$ th building component, $B t u / h \cdot f t^{2} \cdot F$ $\left(\mathrm{W} / \mathrm{m}^{2} \cdot \mathrm{K}\right)$;

$A_{i}=$ surface area for the $i$ th bullding component, $\mathrm{ft}^{2}\left(\mathrm{~m}^{2}\right)$;

$\mathrm{p}^{\mathrm{i}}=$ density of air, $\mathrm{lb} / \mathrm{ft}^{3}\left(\mathrm{~kg} / \mathrm{m}^{3}\right)$

$\mathrm{V}=$ inside volume, $\mathrm{ft}^{3}\left(\mathrm{~m}^{3}\right)$;

I = rate of infiltration, volume changes per hour; and

${ }^{\circ} \mathrm{C}_{\mathrm{p}}=$ specific heat of air, Btu/lb・F $(\mathrm{J} / \mathrm{kg} \cdot \mathrm{K})$

Using eq. (3), the envelope heat-transfer cuefficient (K) for Building No. 2 was computed to be $199 \mathrm{Btu} / \mathrm{h} \cdot \mathrm{F}(105 \mathrm{~W} / \mathrm{K})$. This value agrees within $3.5 \%$ of the slope for the TARP computer predictions and within $8.3 \%$ for the EMPS computer predictions. These results indicate that for these six test buildings TARP predicts the envelope heat-transfer coefficient more closely than EMPS.

\section{SUMMARY AND CONCLUSIONS}

Computer predictions using TARP and EMPS followed closely the general trends 
of the measured sensible conditioning loads for the six test buildings, thereby supporting the validity of both the computer programs and the measured data. TARP tended to provide better agreement between predicted and measured sensible heating loads during winter and spring heating periods, while EMPS provided better agreement during summer cooling periods. During the winter period, TARP predicted cumulative sensible heating loads within an RMS average difference of $11.5 \%$ and peak sensible heating loads within an RMS average difference of $12.1 \%$. During the summer period, EMPS predicted cumulative sensible cooling loads within an RMS average difference of $14.8 \%$ and peak cooling loads within an RMS average difference of $16.5 \%$. This agreement is good in view of the uncertainties associated with the measurements, uncertainty for the heat-transfer properties comprising the building envelope, and the simplifying approximations used in the computer algorithms.

\section{ACKNOWLEDGMENTS}

This study was sponsored by the Electric Power Research Institute.

\section{REFERENCES}

1. D. M. Burch, D. F. Krintz, and R. S. Spain, "The Effect of Wall Mass on Winter Heating Loads and Indoor Comfort - An Experimental Study," ASHRAE Transactions, Vol. 90, Part 1, 1984.

2. D. M. Burch, K. L. Davis, and S. A. Malcolm, "The Effect of Wall Mass on the Summer Space Cooling of Six Test Buildings," ASHRAE Transactions, Vol. 90, Part 2, 1984.

3. F. Y. Sorre11, T. J. Luckenback, and T. L. Phelps, "Validation of Hourly Building Energy Models for Residential Buildings," ASHRAE Transactions, Vol. 91, Part 2, 1985.

4. G. N. Walton, "Thermal Analysis Research Program - Reference Manual," NBSIR 83-2655, National Bureau of Standards, 1983.

5. R. L. Merriam and R. J. Rancatore, "EMPS 2.1 Computer Program for Residential Building Energy Analysis - Engineering Manual," Report No. 1830-4, Arthur D. Little, Inc., 1985, Cambridge, MA 02140.

6. D. M. Burch, W. E. Remmert, D. F. Krintz, and C. S. Barnes, "A Field Study of the Effect of Wall Mass on the Heating and Cooling Loads of Residential Buildings," Proceedings of the Building Thermal Mass Seminar, Oak Ridge National Laboratory CONF-8206130, 1982, Oak Ridge, TN.

7. F. Arumi-Noe, "Anomalous Heat Losses in the NBS Thermal Mass House 6 -- Three Dimensional DEROB Simulation," Contract Report, School of Architecture, University of Texas, 1983, Austin, TX.

8. F. Arumi-Noe and D. M. Burch, "DEROB Simulation of the NBS Thermal Mass Test Buildings," ASHRAE Transactions, Vol. 90, Part 2, 1984.

9. D. M. Burch, B. A. Peavy, and F. J. Powe11, "Comparison Between Measured and Computer-Predicted Hourly Heating and Cooling Energy Requirements for an Instrumented Wood Frame Townhouse Subjected to Laboratory Tests," ASHRAE Transactions, Vo1. 81, Part 2, 1975. 
10. R. Judkoff, D. Wortman, and J. Burch, "Measured Versus Predicted Performance of the SERI Test House: A Validation Study," National Heat Transfer Conference, Seattle, WA, July, 1983.

11. B. Anderson, F. Bauman, and R. Kammerud, "Verification of BLAST by Comparison with Direct Gain Test Cell Measurements," Lawrence Berkeley Laboratory, Report No. LBL-10619, Nov., 1980. 
TABLE 1

Properties of the Exterior Walls of the Test Buildings

\begin{tabular}{|c|c|c|c|c|c|c|}
\hline \multirow{2}{*}{$\begin{array}{c}\text { Building } \\
\text { No. }\end{array}$} & \multicolumn{2}{|c|}{ Thermal Resistance } & \multicolumn{2}{|c|}{ Mass } & \multicolumn{2}{|c|}{$\begin{array}{l}\text { Active } \\
\text { mal Ca }\end{array}$} \\
\hline & $h \cdot f t^{2} \cdot E / B t u$ & $\mathrm{~m}^{2} \cdot \mathrm{K} / \mathrm{W}$ & $1 \mathrm{~b} / \mathrm{ft} \mathrm{t}^{2}$ & $\mathrm{~kg} / \mathrm{m}^{2}$ & $\mathrm{Btu} / \mathrm{F}$ & $\mathrm{MJ} / \mathrm{K}$ \\
\hline 1 & 12.2 & 2.1 & 4.4 & 21 . & 283. & 0.54 \\
\hline 2 & 3.6 & 0.63 & 4.2 & 21 . & 283. & 0.54 \\
\hline 3 & 13.7 & 2.4 & 64. & 310 & 283. & 0.54 \\
\hline 4 & 4.6 & 0.81 & 42 & 210 & 283 . & 0.54 \\
\hline 5 & 10.3 & 1.8 & 17. & 83. & $1540 . \mathrm{b}$ & 2.9 \\
\hline 6 & 12.4 & 2.2 & 83. & 410 & 4470 & 8.5 \\
\hline
\end{tabular}

a Here the term "active thermal capacitance" refers to thermal capacitance interior to the insulation or cavity air space of the exterior wall system.

b Based on one-half $\log$ thickness. 
Table 2

Comparison of Predicted Sensible Heating Loads to Corresponding Measured Loads for the Winter Heating Period

\section{A. TARP}

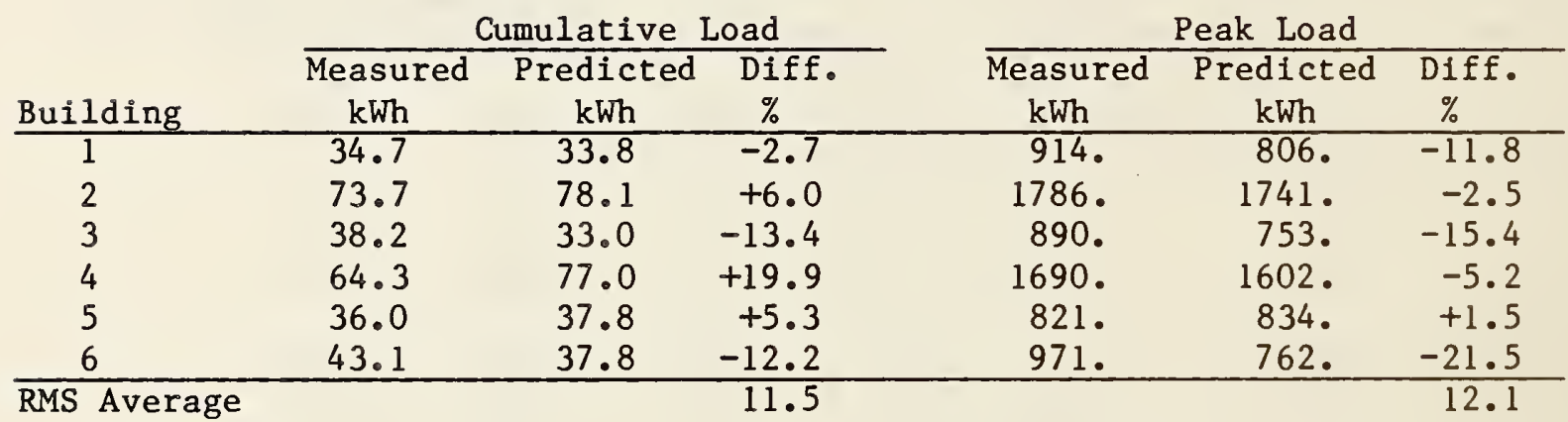

B. EMPS

\begin{tabular}{|c|c|c|c|c|c|c|}
\hline \multirow[b]{2}{*}{ Building } & \multicolumn{3}{|c|}{ Cumulative Load } & \multicolumn{3}{|c|}{ Peak Load } \\
\hline & $\begin{array}{l}\text { Measured } \\
\mathrm{kWh}\end{array}$ & $\begin{array}{c}\text { Predicted } \\
\text { kWh }\end{array}$ & $\underset{\%}{\text { Diff. }}$ & $\begin{array}{c}\text { Measured } \\
\mathrm{kWh}\end{array}$ & $\begin{array}{c}\text { Predicted } \\
\mathrm{kWh}\end{array}$ & $\begin{array}{l}\text { Diff. } \\
\%\end{array}$ \\
\hline 1 & 34.7 & 31.4 & -9.7 & 914. & 742 . & -18.8 \\
\hline 2 & 73.7 & 86.3 & +17.2 & 1786. & 1895. & +6.1 \\
\hline 3 & 38.2 & 30.0 & $-21 \cdot 4$ & 890. & 693. & -22.1 \\
\hline 4 & 64.3 & 83.2 & +29.5 & 1690. & 1729. & +2.3 \\
\hline 5 & 36.0 & 34.7 & -3.3 & 821 . & 742 . & -9.6 \\
\hline 6 & 43.1 & 33.7 & -21.7 & 971. & 703. & -27.6 \\
\hline RMS Ave & & & 19.1 & & & 17.0 \\
\hline
\end{tabular}


Table 3

Comparison of Predicted Sensible Heating Loads to Corresponding Measured Loads for the Spring Heating Period

\section{A. TARP}

\begin{tabular}{|c|c|c|c|c|c|c|}
\hline \multirow[b]{2}{*}{ Building } & \multicolumn{3}{|c|}{ Cumulative Load } & \multicolumn{3}{|c|}{ Peak Load } \\
\hline & $\begin{array}{c}\text { Measured } \\
\text { kWh }\end{array}$ & $\begin{array}{c}\text { Predicted } \\
\mathrm{kWh}\end{array}$ & $\begin{array}{c}\text { Diff. } \\
\%\end{array}$ & $\begin{array}{l}\text { Measured } \\
\text { kWh }\end{array}$ & $\begin{array}{c}\text { Predicted } \\
\mathrm{kWh}\end{array}$ & $\begin{array}{c}\text { Diff. } \\
\%\end{array}$ \\
\hline 1 & 15.7 & 12.4 & -20.8 & 663. & 693. & +4.6 \\
\hline 2 & 42.4 & 38.9 & -8.2 & 1640. & 1641. & +0.09 \\
\hline 3 & 13.1 & 9.18 & $-30 \cdot 0$ & 540. & 518. & $-4 \cdot 1$ \\
\hline 4 & 24.5 & 31.6 & +29.0 & 1105. & 1173. & +6.1 \\
\hline 5 & 9.96 & 9.89 & -0.8 & 514. & 520. & +1.3 \\
\hline 6 & 8.40 & 4.70 & -44.1 & 449. & 325. & -27.7 \\
\hline RMS Ave & & & 26.4 & & & 11.9 \\
\hline
\end{tabular}

B. EMPS

\begin{tabular}{ccccccccc} 
& \multicolumn{3}{c}{ Cumulative Load } & & \multicolumn{3}{c}{ Peak Load } \\
\cline { 2 - 4 } Building & $\begin{array}{c}\text { Measured } \\
\mathrm{kWh}\end{array}$ & $\begin{array}{c}\text { Predicted } \\
\mathrm{kWh}\end{array}$ & $\begin{array}{c}\text { Diff. } \\
\%\end{array}$ & & $\begin{array}{c}\text { Measured } \\
\mathrm{kWh}\end{array}$ & $\begin{array}{c}\text { Predicted } \\
\mathrm{kWh}\end{array}$ & $\begin{array}{c}\text { Diff. } \\
\%\end{array}$ \\
\hline 1 & 15.7 & 11.8 & -24.6 & & 663 & \\
2 & 42.4 & 45.8 & +8.0 & & 1640. & 1768. & +7.8 \\
3 & 13.1 & 8.12 & -38.1 & & 540. & 440. & -18.5 \\
4 & 24.5 & 36.3 & +47.8 & & 1105. & 1260. & +14.0 \\
5 & 9.96 & 9.43 & -5.3 & & 514. & 440. & -14.4 \\
6 & 8.40 & 4.07 & -51.5 & & 449. & 283. & -37.0 \\
\hline RMS & Average & & & 34.4 & & & &
\end{tabular}


Table 4

Comparison of Predicted Sensible Cooling Loads to Corresponding Measured Loads for the Summer Cooling Period

\section{A. TARP}

\begin{tabular}{cccccccc} 
& \multicolumn{3}{c}{ Cumulative Load } & & \multicolumn{3}{c}{ Peak Load } \\
\cline { 2 - 4 } Building & $\begin{array}{c}\text { Measured } \\
\mathrm{kWh}\end{array}$ & $\begin{array}{c}\text { Predicted } \\
\mathrm{kWh}\end{array}$ & $\begin{array}{c}\text { Diff } \\
\%\end{array}$ & & $\begin{array}{c}\text { Measured } \\
\mathrm{kWh}\end{array}$ & $\begin{array}{c}\text { Predicted } \\
\mathrm{kWh}\end{array}$ & $\begin{array}{c}\text { Diff. } \\
\%\end{array}$ \\
\hline 1 & 100.4 & 116.2 & 15.6 & & 3280 & 3544. & 8.0 \\
2 & 140.5 & 151.5 & 7.8 & & 5276. & 5608. & 6.2 \\
3 & 78.5 & 107.3 & 36.6 & & 2166. & 2811. & 29.8 \\
4 & 91.6 & 124.5 & 35.8 & & 2917. & 3950. & 35.0 \\
5 & 81.6 & 99.2 & 21.6 & & 2155. & 2661. & 23.5 \\
6 & 69.6 & 82.1 & 18.1 & & 1576. & 2183. & 38.5 \\
\hline RMS Average & & & 24.9 & & & & 26.6
\end{tabular}

B. EMPS

\begin{tabular}{|c|c|c|c|c|c|c|}
\hline \multirow[b]{2}{*}{ Building } & \multicolumn{3}{|c|}{ Cumulative Load } & \multicolumn{3}{|c|}{ Peak Load } \\
\hline & $\begin{array}{l}\text { Measured } \\
\mathrm{kWh}\end{array}$ & $\begin{array}{c}\text { Predicted } \\
\mathrm{kWh}\end{array}$ & $\begin{array}{l}\text { Diff. } \\
\%\end{array}$ & $\begin{array}{l}\text { Measured } \\
\mathrm{kWh}\end{array}$ & $\begin{array}{c}\text { Predicted } \\
\mathrm{kWh}\end{array}$ & $\begin{array}{l}\text { Diff. } \\
\%\end{array}$ \\
\hline 1 & 100.5 & 99.2 & $-1 \cdot 3$ & 3280 & 2967. & -9.5 \\
\hline 2 & 140.5 & 147.9 & 5.2 & 5276. & 5467. & 3.6 \\
\hline 3 & 78.5 & 29.6 & 17.9 & 2166 & 2333. & 7.7 \\
\hline 4 & 91.6 & 119.3 & 30.3 & 2917. & 3767 . & 29.1 \\
\hline 5 & 81.6 & 82.5 & 1.1 & 2155. & 2133. & -1.0 \\
\hline 6 & 69.6 & 74.5 & 7.1 & 1576. & 1967. & 24.8 \\
\hline
\end{tabular}




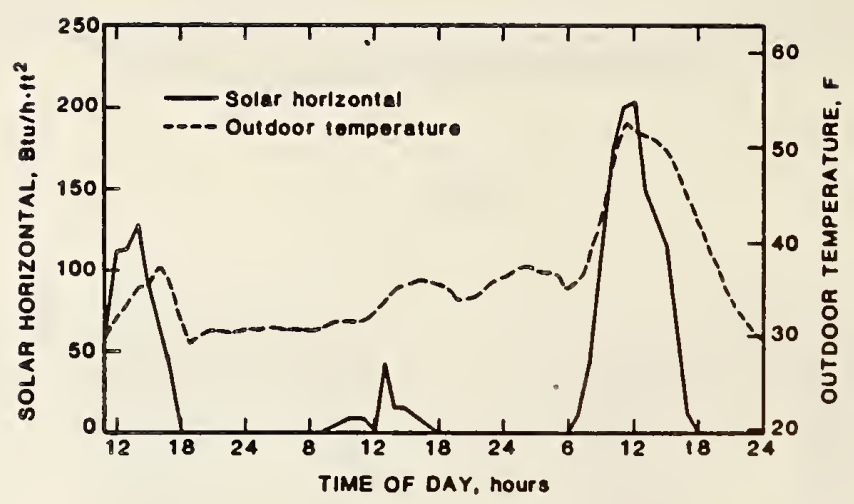

A. Winter heating period

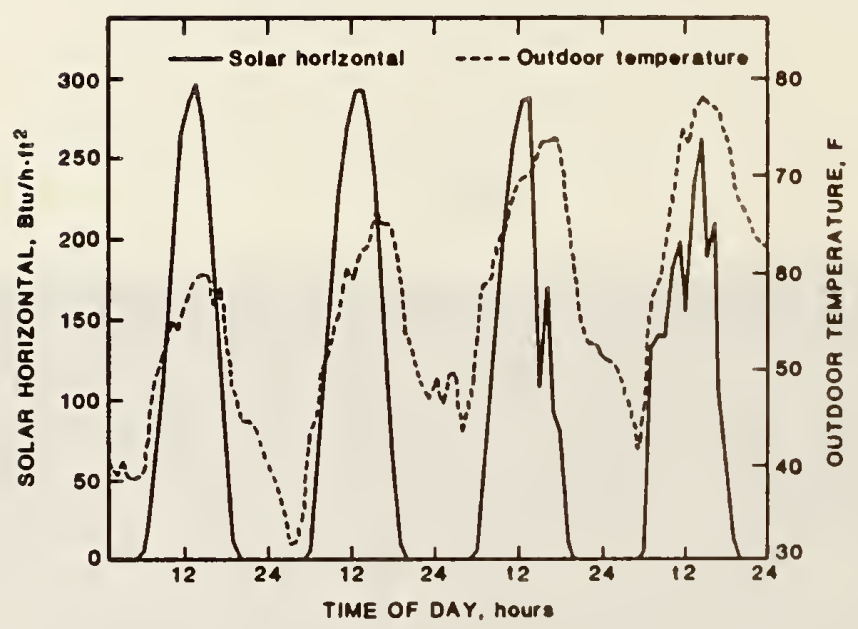

B。 Spring heating period

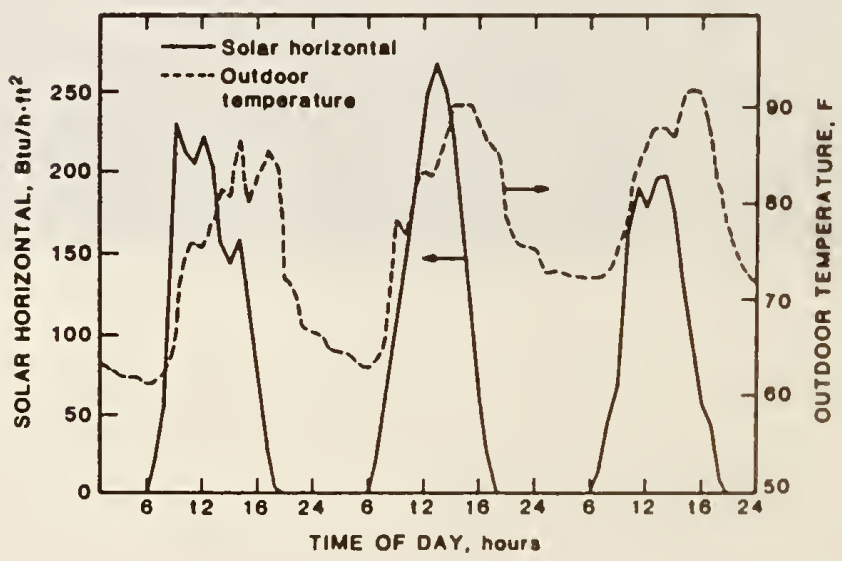

C. Summer cooling period

Fig. 2. Climatic data for the three load comparison periods 


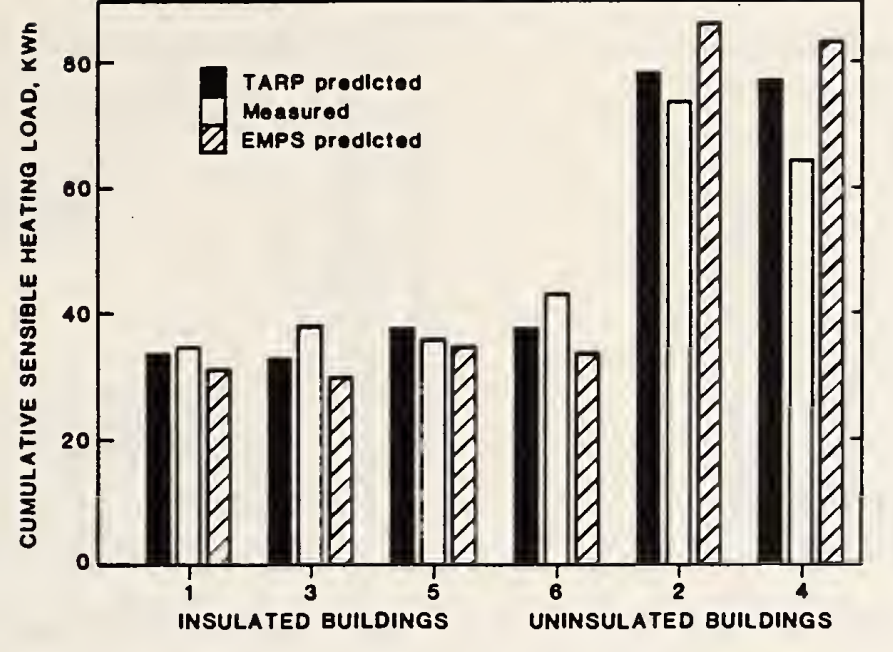

A. Winter heating period

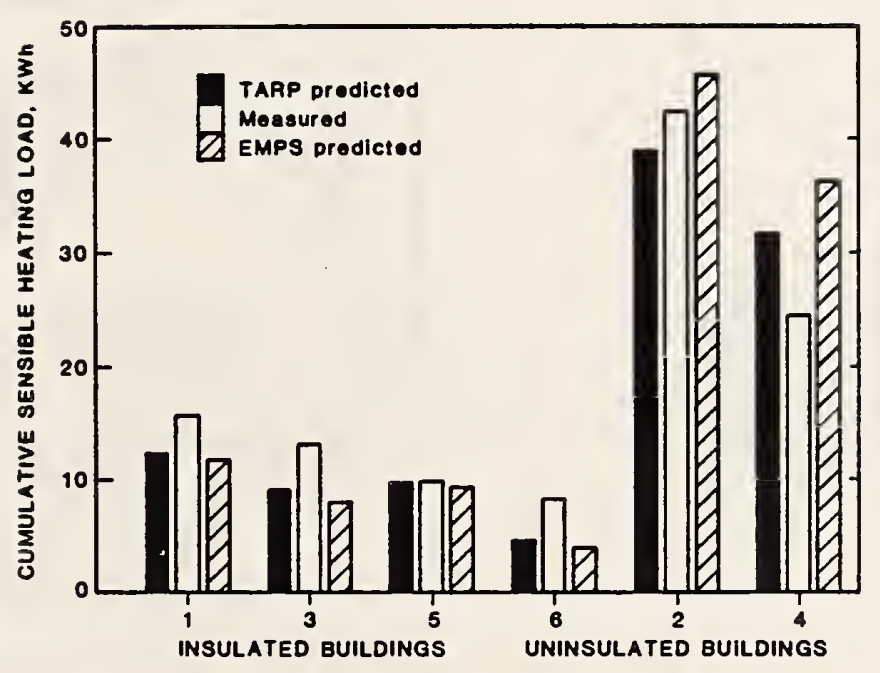

B. Spring heating period

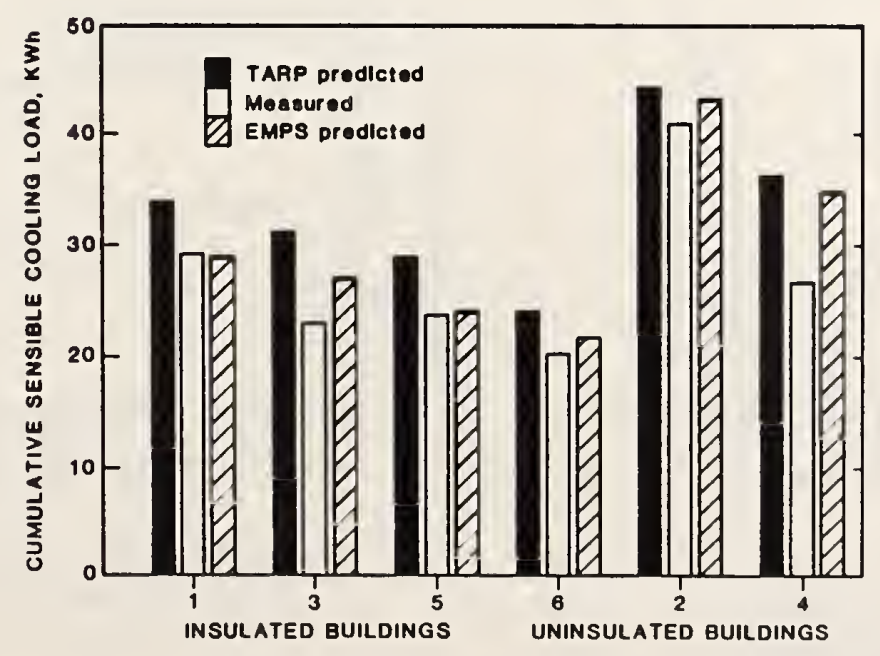

C. Summer cooling period

Fig. 3. Comparison of predicted cumulative sensible conditioning loads to corresponding measured loads for the six test buildings

17 


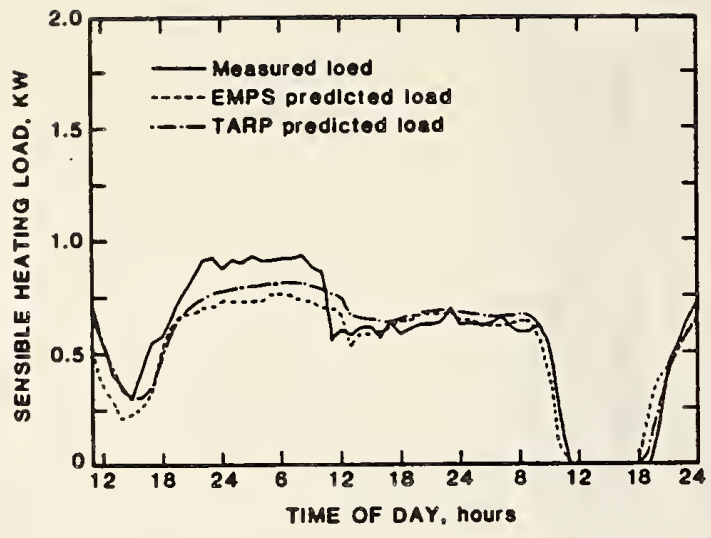

A. Insulated wood frame (No. 1)

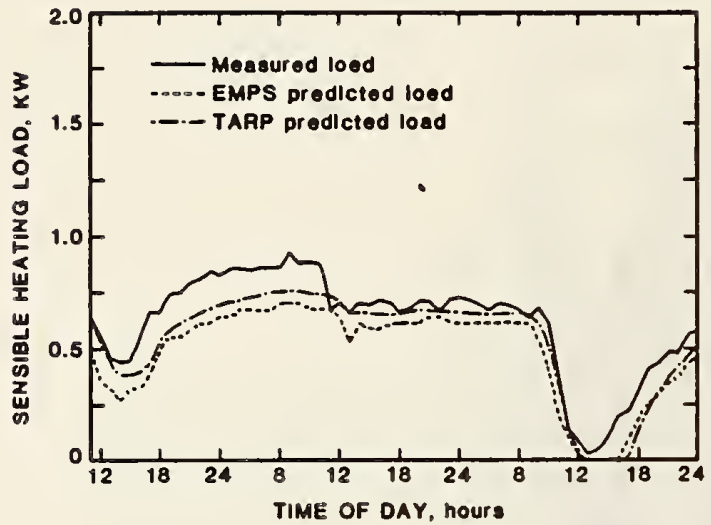

C. Insulated masonry with outside mass (No. 3)

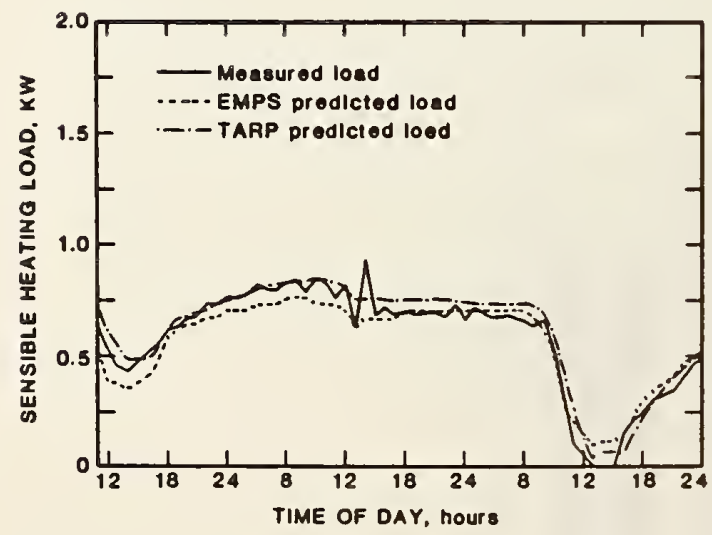

E. $\log$ (No. 5)

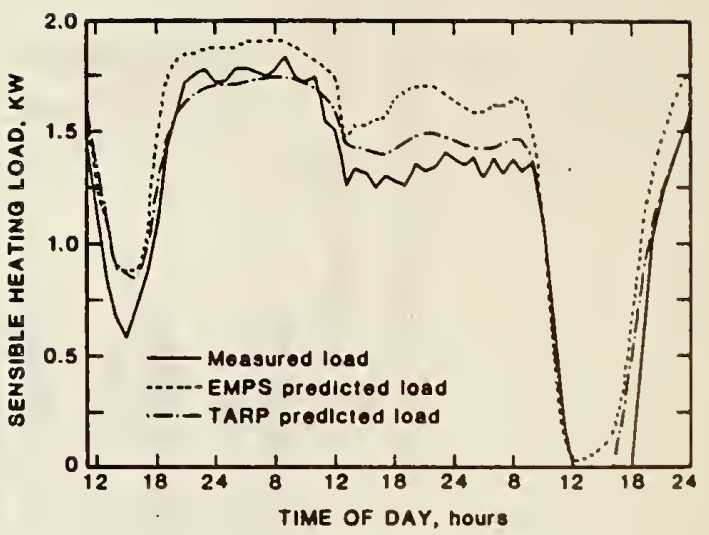

B. Uninsulated wood frame (No. 2)

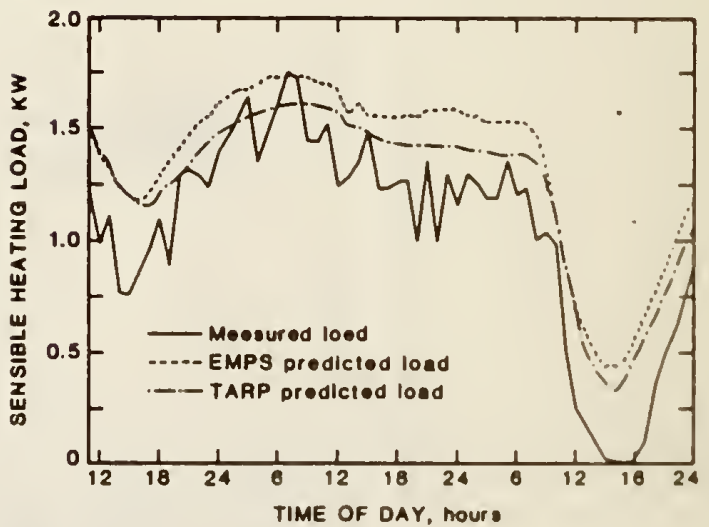

D. Uninsulated masonry (No. 4)

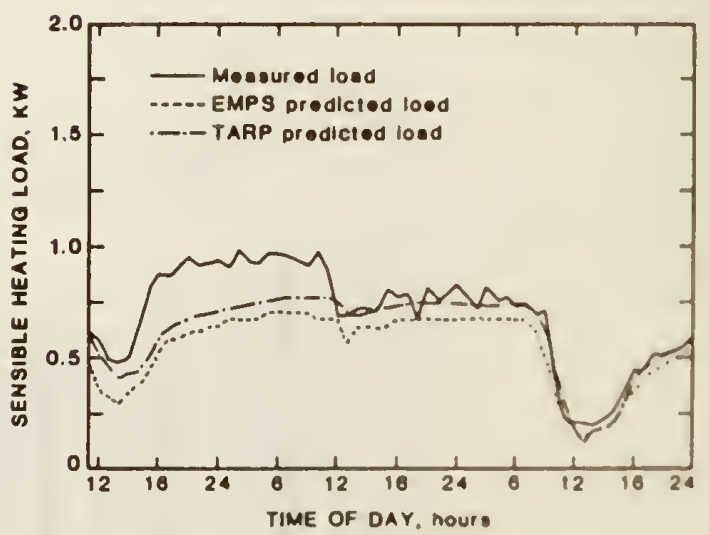

F. Insulated masonry with insulation sandwiched between inside and outside mass (No.6)

Fig. 4. Comparison of predicted sensible heating loads using TARP and EMPS to corresponding measured loads for the $s 1 x$ test bulldings during the winter heating period 


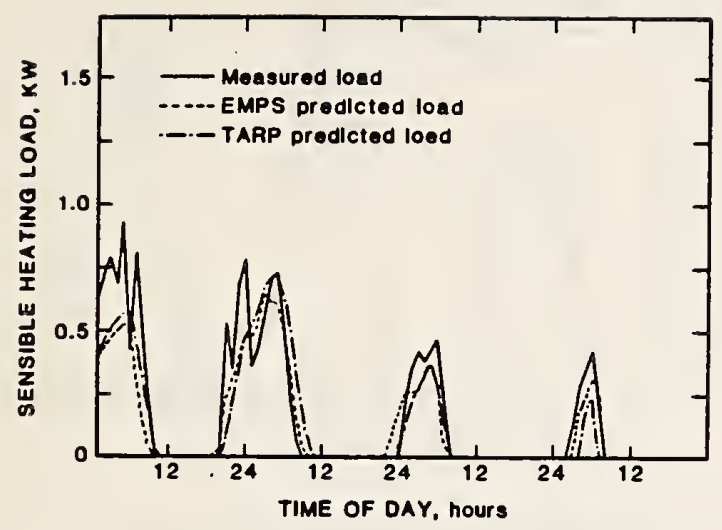

A. Insulated wood frame (No. 1)

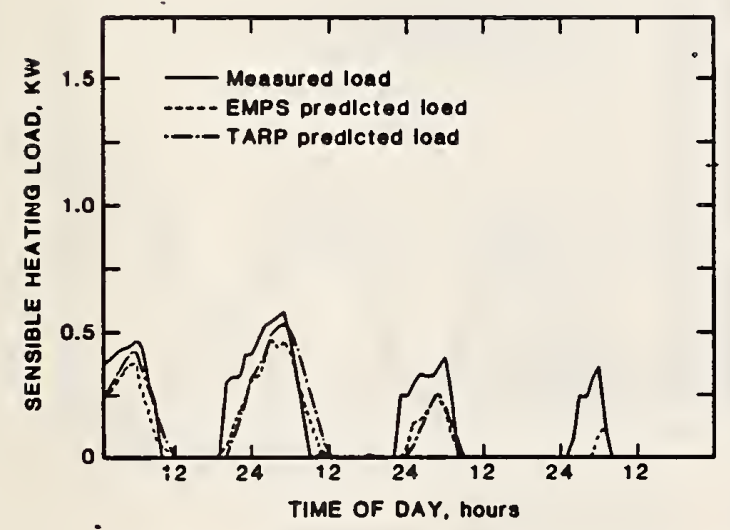

C. Insulated masonry with outside mass (No. 3)

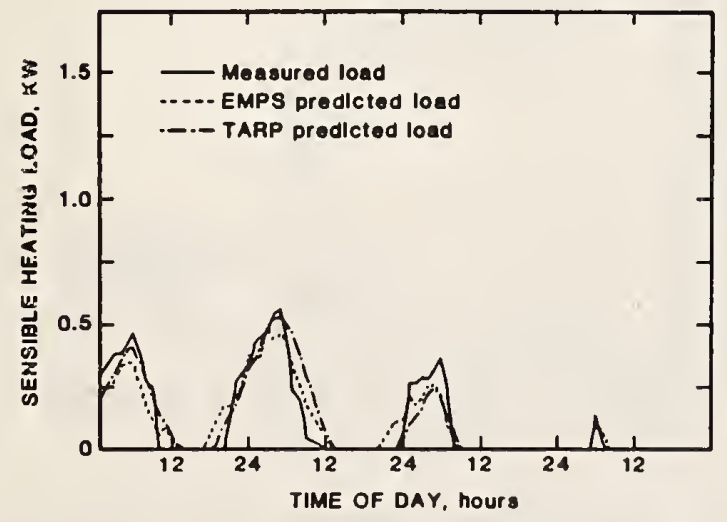

E. $\log ($ No. 5)

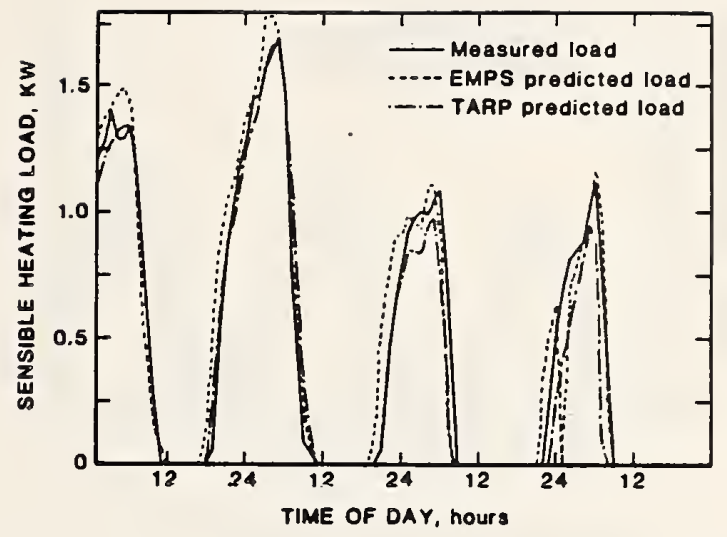

B. Uninsulated wood frame (No. 2)

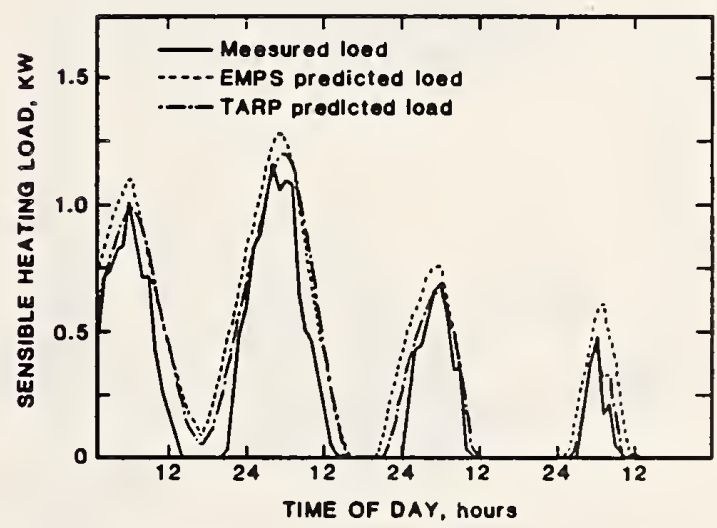

D. Uninsulated masonry (No. 4)

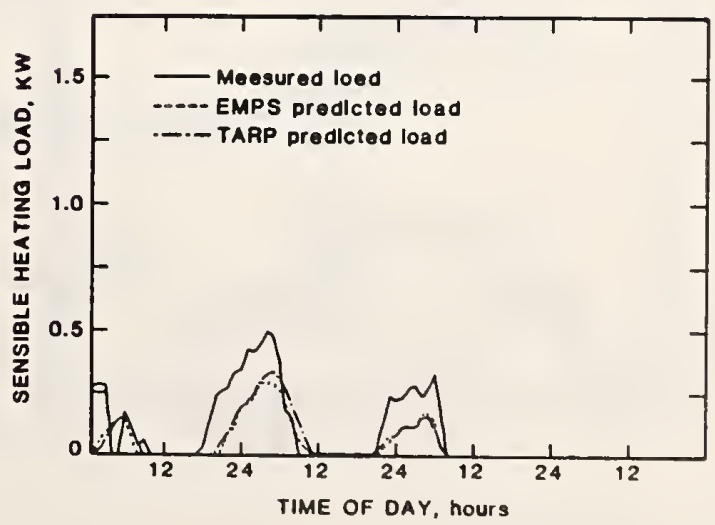

F. Insulated masonry with insulation sandwiched between inside and outside mass (No. 6)

Fig. 5. Comparison of predicted sensible heating loads using TARP and EMPS to corresponding measured loads for the six test buildings during the spring heating period 


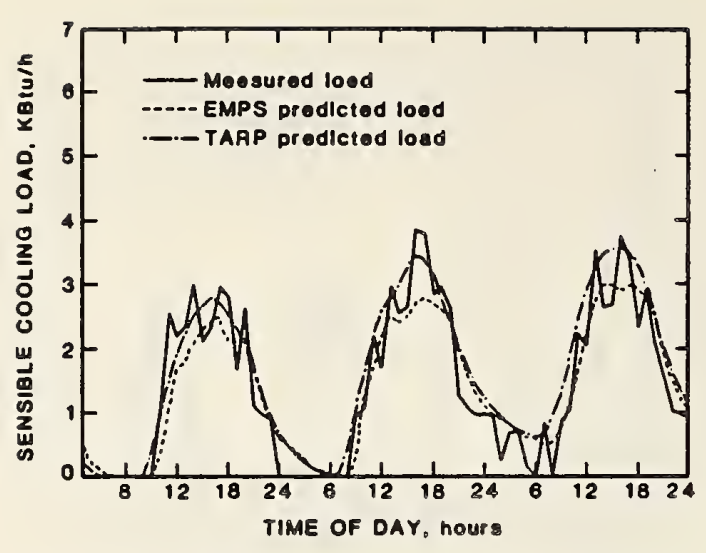

A. Insulated wood frame (No. 1)

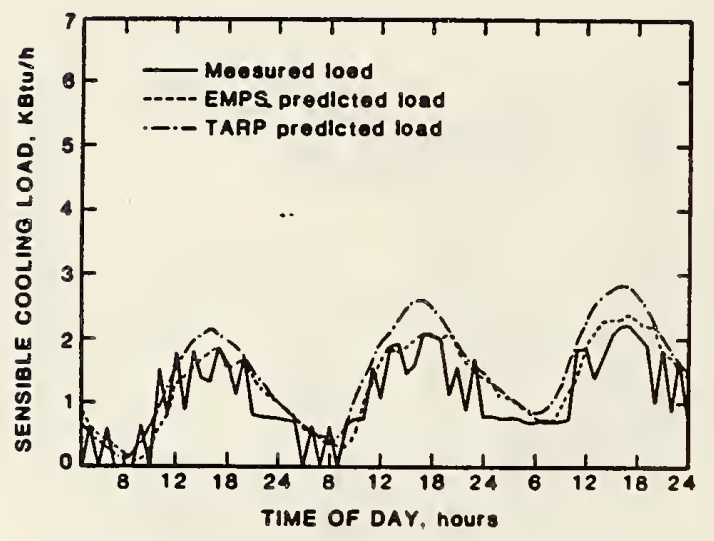

C. Insulated masonry with outside mass (No. 3)

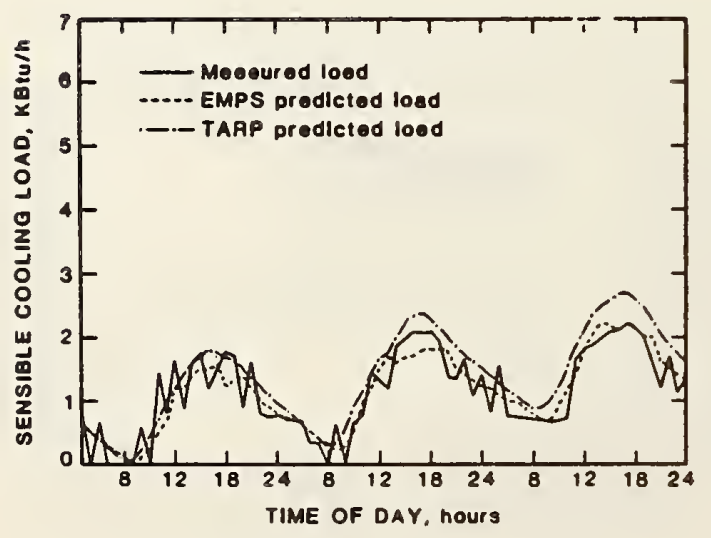

E. Log (No. 5)

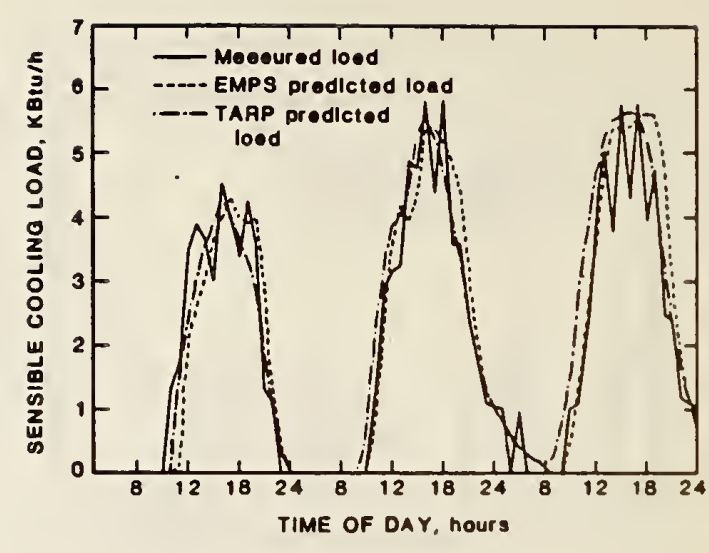

B. Uninsulated wood frame (No. 2)

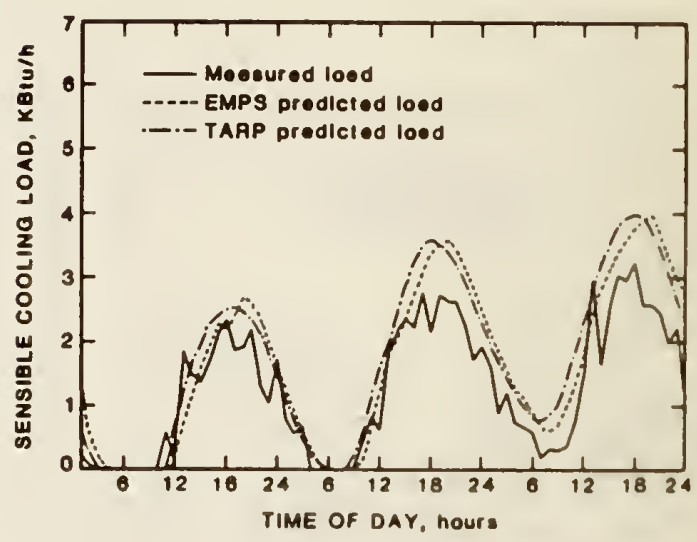

D. Uninsulated masonry (No. 4)

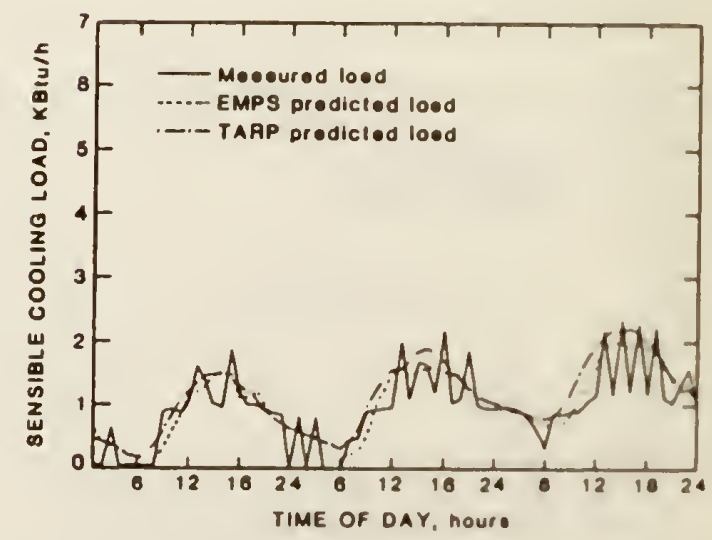

F. Insulated masonry with insulation sandwiched between inside and outside mass (No.6)

Fig. 6. Comparison of predicted sensible cooling loads using TARP and EMPS to corresponding measured loads for the six test bulldings during the summer cooling period 

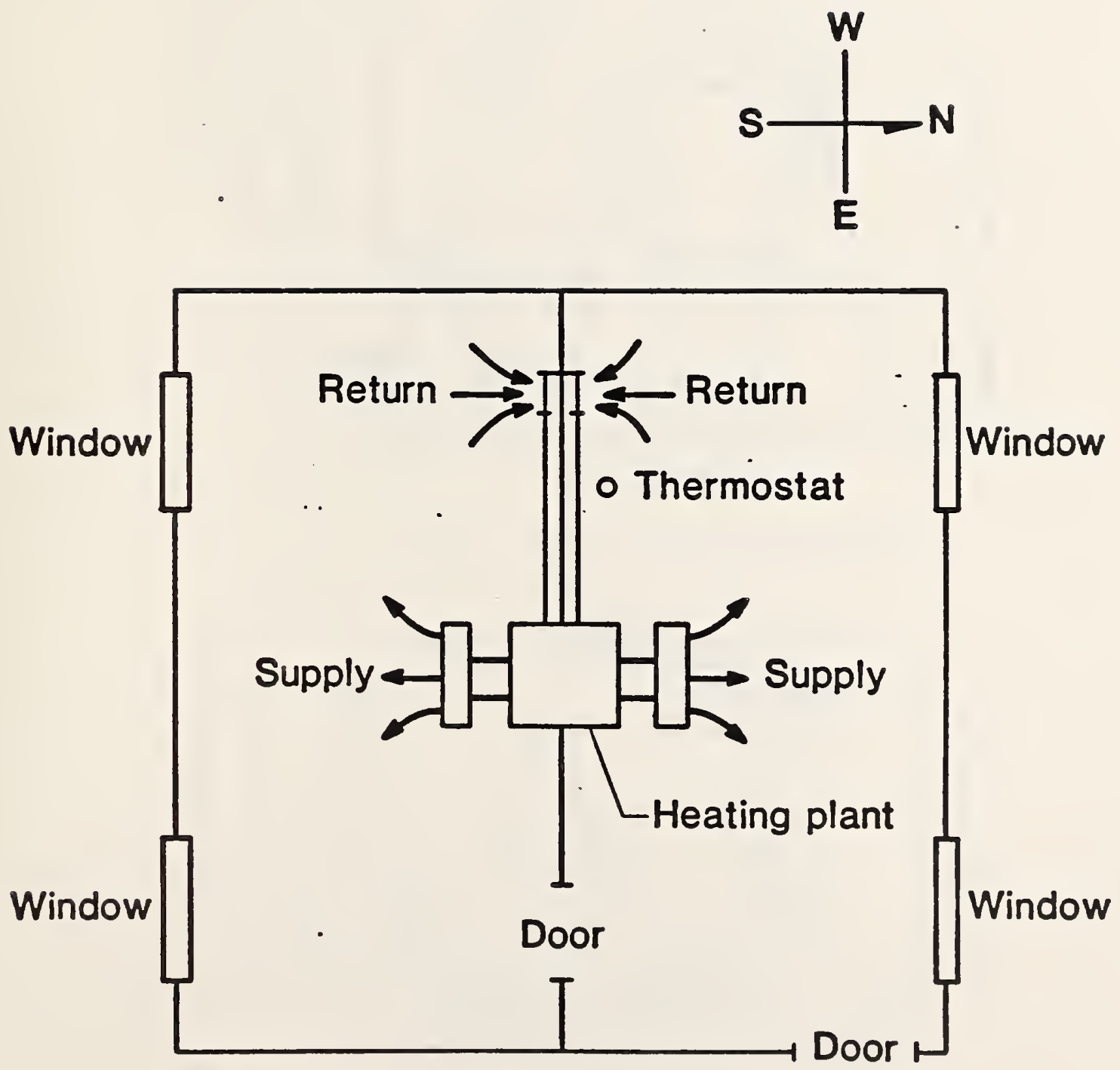

F1g. 7. Schematic of test bullding No. 2 showing the partition wall 


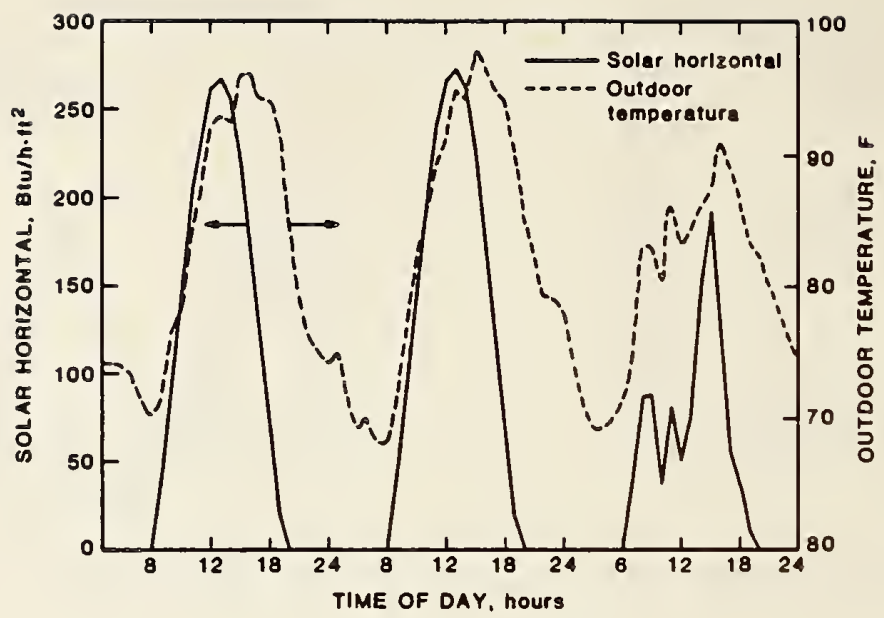

4. Jutdoor climate

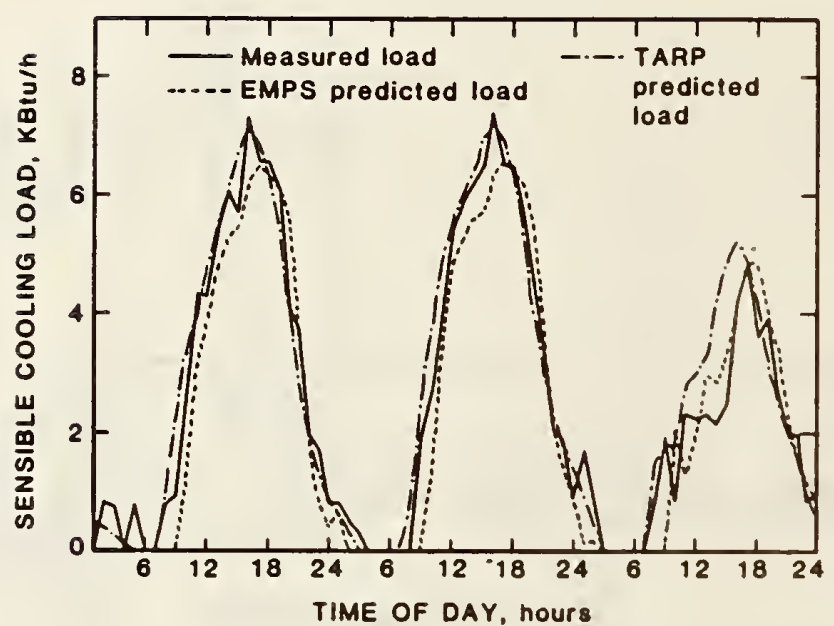

B. Uninsulated wood-frame (No. 2)

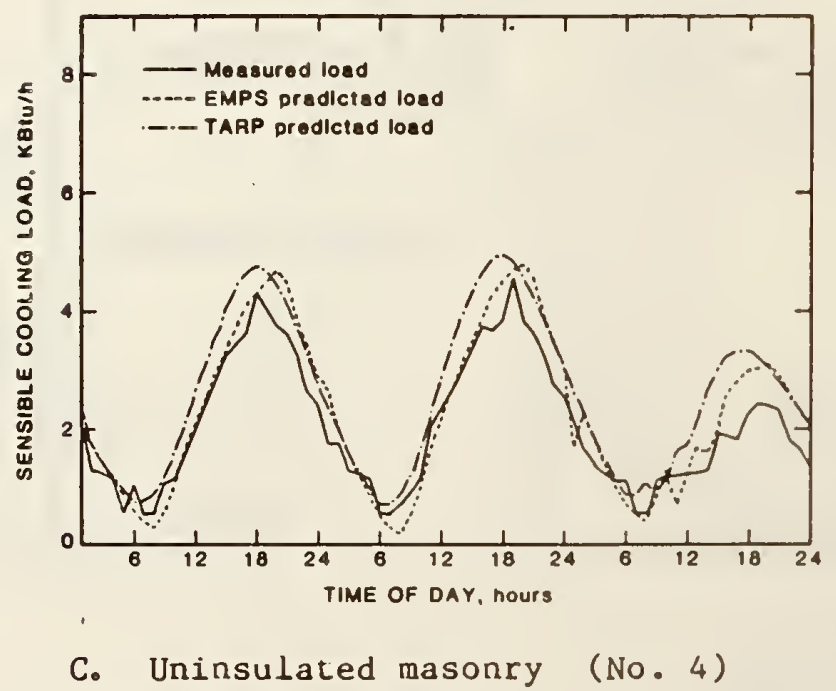

Fig. 8. Comparison of predicted sensible cooling loads using TARP and EMPS to corresponding measured loads for the uninsulated lest buildings with a particion wall but without offlce furniture 


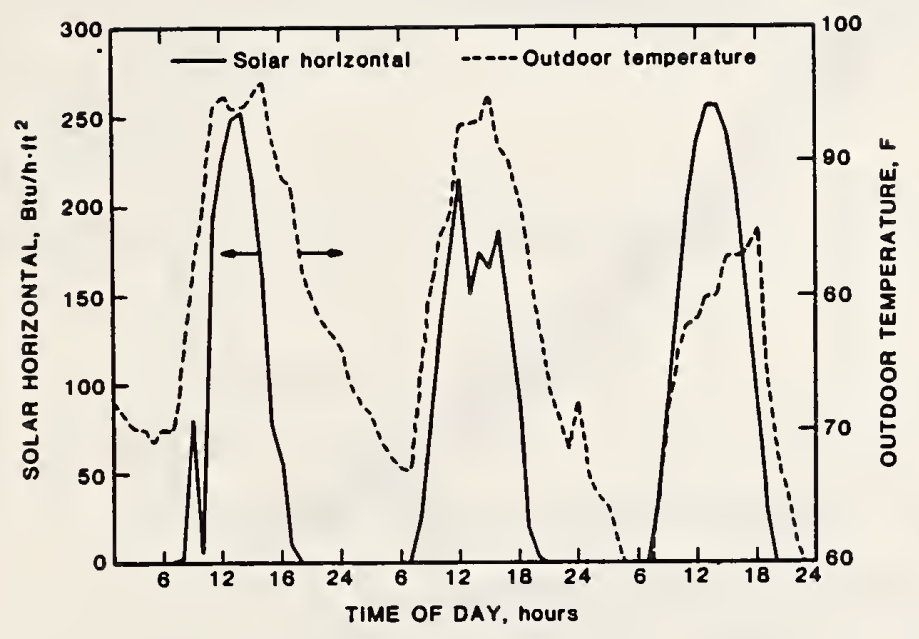

A. Outdoor climatic data

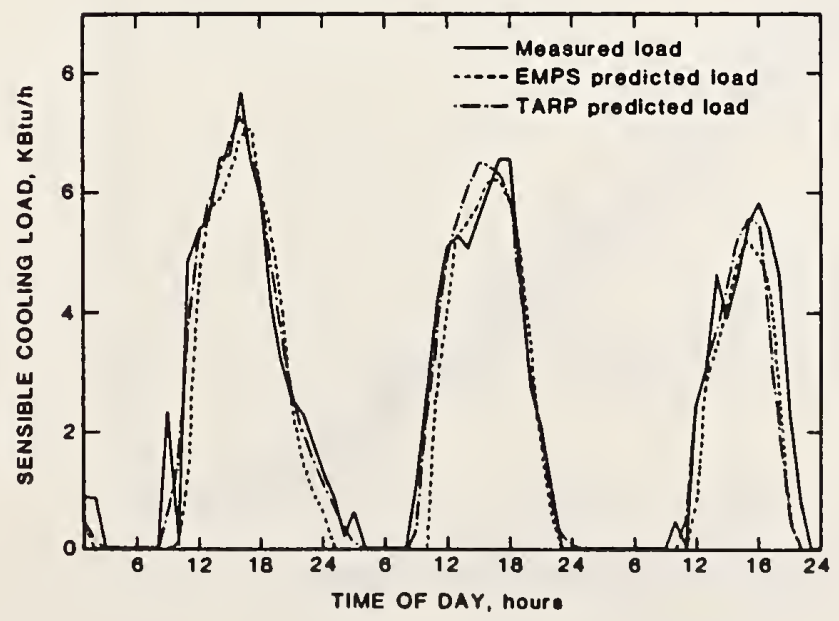

B. Sensible cooling load comparisons

Fig. 9. Comparison of sensible cooling loads predicted using TAKP and EMPS to corresponding measured loads for the uninsulated wood-frame test building (No. 2) with a partition wall and office furniture 


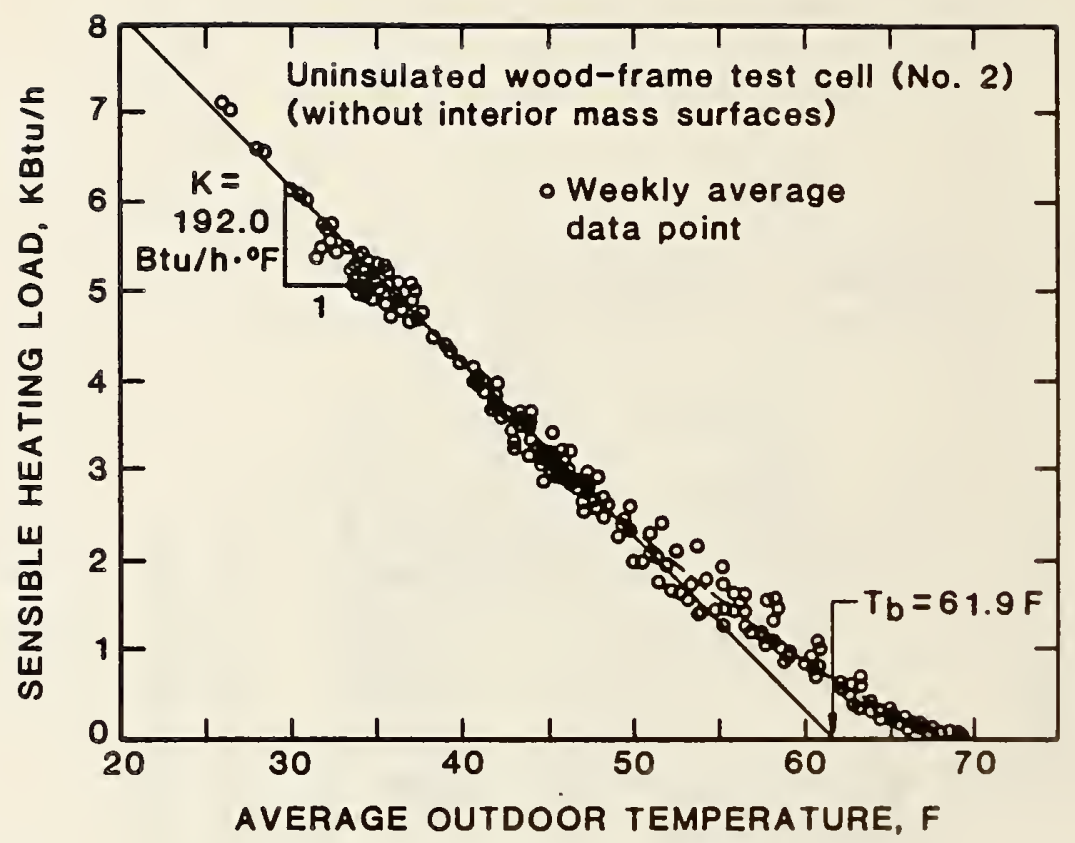

A. TARP

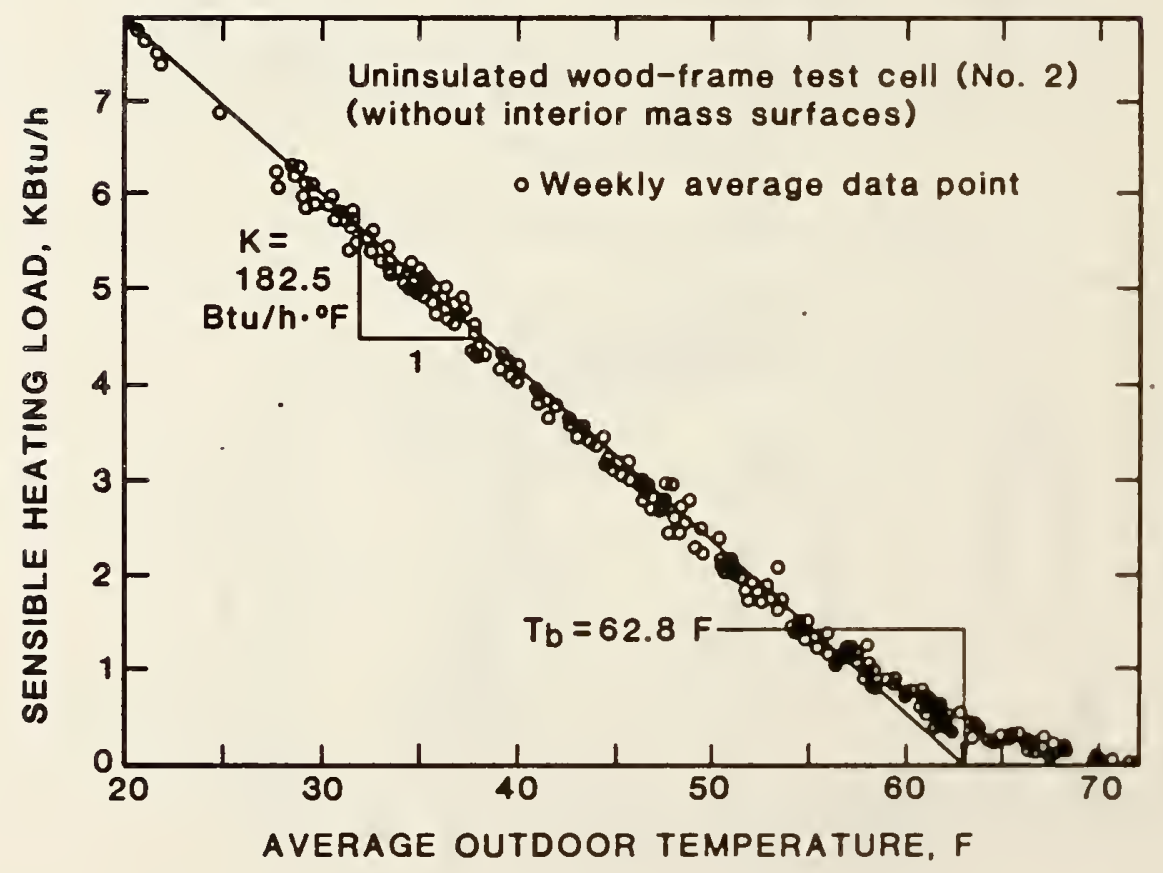

B. EMPS

Fig. 10. Comparison of predicted heating load correlations to steady-state theory 


\section{NBS.114A (REV. 2.8C)}

U.S. DEPT. OF СOMM.

BIBLIOGRAPHIC DATA

SHEET (See instructions)

1. PUBLICATION OR REPORT NO.

NBSIR 86-3399
2. Performing Organ. Report Nof 3. Publication Date

JUNE 1986

4. TITLE AND SUBTITLE

COMPARISON OF MEASURED AND PREDICTED SENSIBLE HEATING AND COOLING LOADS FOR SIX TEST BUILDINGS

5. $A \cup T H O R(S)$

D. M. Burch, G. N. Walton, B. A. Licitra, and R. Cavanaugh

6. PERFORMING ORGANIZATION (If joint or other than NBS, see in structions)

7. Contract/Grant No.

NATIONAL BUREAU OF STANDARDS

DEPARTMENT OF COMMERCE

WASHINGTON, D.C. 20234

8. Type of Report \& Period Covered

9. SPONSORING ORGANIZATION NAME AND COMPLETE ADDRESS (Street。 City. State, ZIP)

EPRI

10. SUPPLEMENTARY NOTES

Document describes a computer program; SF-185, FIPS Software Summary, is attached.

11. ABSTRACT (A 200-word or less factual summary of most significant information. If document includes a significant

bibliography or literature survey. mention it here)

Hourly sensible heating and cooling loads for six test buildings were predicted using two computer programs, called TARP and EMPS. The predicted loads were compared to corresponding measured loads for winter heating, spring heating, and summer cooling periods. Both computer programs predicted the general trends of the measured data. During the winter period, cumulative sensible heating loads predicted by TARP agreed with measured 10 ads within an RMS average difference of $11.5 \%$, and predicted peak sensible heating loads agreed within an RMs average difference of $12.1 \%$. During the winter period, poorer agreement was obtained with EMPS. During the summer period, cumulative sensible cooling loads predicted by EMPS agreed with measured loads within an RMS average difference of $14.8 \%$, and predicted peak sensible cooling loads agreed within an RMS average difference of $16.5 \%$. During the summer period, poorer agreement was obtained with TARP. The agreement between predicted and measured loads is comparable, and in many instances better, than that obtained in similar computer program validation studies.

12. KEY WORDS (Six to twelve entries: alphabetical order: capitalize only proper names: and separate key words by semicolons) Thermal Analysis Research Program (TARP), EPRI Methodology for Preferred Residential Systems (EMPS); Validation of computer programs; Whole Building Performance; Heating Loads; Cooling Loads; and Energy Conservation.

\section{AVAILABILITY}

X Unlimited

$\square$ For Official Distribution. Do Not Release to NTIS $\square$ Order From Superintendent of Documents, U.S. Government Printing Office, Washington, D.C.
20402 .

X] Order From National Technical Information Service (NTIS), Springfield, VA. 22161
14. NO. OF

PRINTED PAGES

28

15. Price 

